\title{
Analisis Personal Branding Selebgram Vincent Raditya di Instagram
}

\author{
Mellisa, H.H.Daniel Tamburian. \\ Mellisa.915160018@stu.untar.ac.id,Danielt@fikom.untar.ac.id
}

Fakultas Ilmu Komunikasi Universitas Tarumanagara

\begin{abstract}
Vincent Raditya is one of the active and loyal users of the Instagram. Vincent Raditya uses Instagram in addition to sharing information and to communicate with his followers, it also forms his Personal Branding. The purpose of this research is to know how Vincent Raditya formed Personal Branding and what Vincent Raditya's Personal Branding looks like on his followers views on Instagram. This study uses interview and documentation methods on Vincent Raditya and 3 of his followers on Instagram. Furthermore, using data analysis techniques, library research and data validity techniques. The theory used in this study is the theory of The Eight Laws of Personal Branding, such as specialization, leadership, personality, distinctiveness, visibility, unity, persistence and goodwill. The results showed that Vincent Radityaformed Personal Branding on Instagram by utilizing the features available on Instagram for a place to work, socialize, share information and experience and means of communication with his followers. Vincent Raditya is seen by followers on Instagram as being kind, humble, multitalented, educating, and caring for the family.
\end{abstract}

Keywords: instagram, personal branding, vincent raditya.

\begin{abstract}
Abstrak
Vincent Raditya merupakan salah satu pengguna aktif dan setia aplikasi Instagram. Vincent Raditya menggunakan Instagram selain untuk berbagi informasi dan untuk berkomunikasi, juga membentuk Personal Branding. Tujuan dari penelitian ini adalah untuk bagaimana Vincent Raditya membentuk Personal Branding dan seperti apa Personal Branding Vincent Raditya pada pandangan pengikut (followers) di Instagram. Penelitian ini menggunakan metode wawancara dan dokumentasi pada Vincent Raditya dan 3 pengikut di Instagram. Selanjutnya menggunakan metode teknik analisis data, studi pustaka dan teknik keabsahan data. Teori yang digunakan dalam penelitian ini yaitu teori The Eight Law Of Personal Branding, yaitu spesialisasi, kepemimpinan, kepribadian, perbedaan, terlihat, kesatuan, keteguhan dan nama baik. Hasil penelitian menunjukan bahwa Vincent Raditya membentuk Personal Branding di Instagram dengan memanfaatkan fitur-fitur yang ada pada Instagram untuk tempat berkarya, bersosialisasi, berbagi informasi dan pengalaman serta sarana komunikasi dengan pengikutnya. Vincent Raditya dipandang oleh pengikut (followers) di Instagram sebagai sosok yang ramah, baik hati, gampang berbaur dengan sesama, mengedukasi, dan sayang keluarga.
\end{abstract}

Kata Kunci: instagram, personal branding, vincent raditya

\section{Pendahuluan}

Vincent Raditya merupakan salah satu pengguna aktif dan setia aplikasi Instagram. Vincent Raditya menggunakan Instagram selain untuk berbagi informasi dan untuk berkomunikasi, Vincent Raditya juga memanfaatkan Instagram untuk mengedukasi dunia aviasi dan juga memperlihatkan aktivitas kesehariannya. 
Perannya sebagai selebgram yang di mana, tugas dan peran selebgram adalah mempromosikan sebuah brand dalam hal ini Vincent Raditya memanfaatkan Instagram dengan mengunggah serangkaian kegiatan yang berhubungan dengan program kerja seperti kegiatan sosial, berita, informasi, dan motivasi yang berhubungan dengan personal branding. Selain itu juga Vincent Raditya mengunggah serangkaian kegiatan pribadi dengan memposting kegiatan-kegiatan kesehariannya seperti, saat bersama keluarga ataupun dengan teman-temannya, agar pengikutnya di Instagram dapat lebih mengenalnya dan melihat kegiatan kesehariannya, serta Vincent Raditya juga memanfaatkan kolom komentar untuk berkomunikasi agar bisa terjalin hubungan yang baik dengan para pengikutnya.

Semua itu konsisten dilakukannya agar bisa terus dilihat oleh khalayak publik dan bisa membangun citra tersendiri bagi seorang Vincent Raditya. Oleh karena itu pengguna Instagram khususnya bagi Vincent Raditya harus bisa membentuk persepsi positif dari postingannya. Saat ini brand tidak hanya diperuntukan untuk barang dan jasa saja, namun kita sendiri mampu menciptakan brand bagi diri kita sendiri, pada manusia brand yang melekat pada dirinya disebut dengan personal branding. Personal branding itu sendiri bertujuan untuk membangun relasi, asosiasi dan harapan pada masyarakat terhadap diri seseorang.

Personal branding adalah cerminan dari kemampuan, keunggulan reputasi yang mana mampu menunjukan keistimewaan dan keunggulan, terlebih lagi bagi Vincent Raditya yang memiliki prestasi dan keunggulan di bidang aviasi dan konten kreator. Raditya, Vincent. (2019)

Berdasarkan penelitian terdahulu yang dikemukakan oleh Stevani dan Widayatmoko dalam jurnal komunikasi yang berjudul Kepribadian Dan Komunikasi Susi Pudjiastuti Dalam Membentuk Personal Branding. Didapatkan hasil bahwa dalam penelitian terbukti bahwa Susi Pudjiastuti memiliki personal branding yang memang sudah melekat dalam persepsi masyarakat mengenai Susi Pudjiastuti dari kepribadian yang baik dan komunikasi yang terbuka dengan orang lain. Stevani dan Widayatmoko. (2017)

Adapun fenomena yang berkaitan dengan branding dalam sosial media Instagram, sekarang banyak sekali selebgram yang bermunculan. Jumlah follower (pengikut) nya pun beragam, ada yang jutaan, ratusan atau masih dibawah 5000 followers saja sudah bisa menjadi seorang selebgram. Fenomena seorang selebgram maupun blogger juga butuh mempromosikan diri melalui personal branding, untuk menunjukan karakteristik masing-masing blogger dan selebgram.

Tingginya pengguna internet di Indonesia diyakini selaras dengan meningkatnya aktivitas di media sosial. Aplikasi yang kerap kali digunakan adalah Instagram, dari hasil survey (wearesocial.com, 2016). Salah satu unsur terpenting dalam penelitian yang memiliki peran sangat besar dalam penelitian adalah teori dan judul penelitian Analisis Personal Branding Selebgram Vincent Raditya di Instagram. Untuk itu penulis menggunakan teori personal branding yang dikemukakan oleh Montaya dan Vandehey yaitu The Eight Law of Personal Branding dan teori reputasi. Teori-teori ini yang akan mendukung proses penelitian agar mendapatkan hasil yang memuaskan.

\section{Metode Penelitian}

Penelitian ini dilakukan untuk mengetahui Bagaimana Personal Branding Selebgram Vincent Raditya di Instagram. Dalam penelitian ini penulis menggunakan 
penelitian kualitatif. Dalam membentuk personal branding di butuhkan konsep yang berguna dimana seperti yang di kemukakan Montoya dan Vandehey (2002), bahwa ada delapan konsep dalam pembentukan personal branding yang dapat digunakan sebagai pondasi yang kuat dalam pembentukan personal brand yang dikenal dengan istilah The eight law of personal branding.

Adapun kedelapan konsep tersebut sebagai berikut :

1. Spesialisasi (The Law of Specialization).

2. Kepemimpinan (The Law of Leadership).

3. Kepribadian (The Law of Personality).

4. Perbedaan (The Law of Distinctiveness).

5. Terlihat (The Law of Visibility).

6. Kesatuan (The Law of Unity).

7. Keteguhan (The Law of Persistence).

8. Nama baik (The Law of Goodwill)

\section{Hasil Penemuan dan Diskusi}

Personal branding merupakan segala kegiatan, aktivitas, perilaku dan semua hal yang berhubungan atas diri sendiri yang dapat mencerminkan siapa diri kita. Kegiatan dan perilaku yang dilakukan dapat menimbulkan keahlian, kepribadian dan karekteristik tersendiri yang terbungkus menjadi sebuah identitas yang dapat membuat seseorang lebih menonjol dari orang lain khususnya bagi Vincent Raditya dalam hal ini memanfaatkan Instagram sebagai media untuk membentuk personal branding nya. Untuk mencapai personal branding yang baik seseorang harus memiliki kesadaran akan dirinya sendiri, menggali potensi yang dimiliki, serta memperbaiki diri dan menjaga akan penampilan yang ingin ditampilkan jika dirasa apa yang dilakukan selama ini memiliki suatu hal yang kurang mendukung untuk mencapai apa yang di cita-citakan, adanya keinginan untuk mengubah kehidupannya menjadi lebih baik dengan menciptakan relasi yang baik di dunia kerja ataupun di kesehariannya serta ingin menunjang karir yang dimiliki ataupun yang lainnya dapat dilakukan dengan personal branding. Melalui penelitian di akun Instagram dari informan Vincent Raditya ditemukan bahwa ia memanfaatkan media sosial seperti Instagram sebagai sarana komunikasi dengan berbagi informasi dan berinteraksi dengan publik sekaligus sebagai sarana untuk membentuk personal branding nya. Ia membentuk personal branding nya melalui Instagram dengan mengunggah berbagai kegiatan kesehariannya sebagai pilot dan konten kreator maupun kegiatan kesehariannya sebagai pribadi yang baik, untuk mengetahui lebih jauh bentuk personal branding Vincent Raditya dengan merujuk pada delapan kunci sukses membentuk personal branding menurut Montoya dan Vandehey dijabarkan sebagai berikut:

\section{1) Spesialisasi (The Law of Specialization) :}

Vincent Raditya merupakan representasi pemuda yang memiliki peran dan tugas sebagai pilot, menjalankan dan menerbangkan pesawat udara. Mengemudikan pesawat terbang adalah tugas utama dari seorang pilot. Kemampuan yang memerlukan tuntutan keahlian tinggi ini memerlukan lisensi sendiri, dan didapatkan melalui ujian yang diselenggarakan sekolah pilot dan juga otoritas yang mengatur penerbangan. Seorang pilot mempunyai tanggung jawab yang besar dalam pekerjaannya, sehingga tidak sembarang orang bisa begitu saja mengantungi lisensi. 
Kemampuan tersebut merupakan salah satu spesialisasi yang dimiliki oleh Vincent Raditya yang dimana spesialisasi dalam membentuk personal branding itu bisa berupa kemampuan atau keahlian serta ciri khas baik dalam gaya hidup ataupun yang lain. Sehingga dalam hal ini dari segi spesialisasi pilot menjadi selebgram menunjukkan ciri khas dari Vincent Raditya.

2) Kepemimpinan (The Law of Leadership) :

Kepemimpinan bisa berupa keunggalan atau penghargaan tertentu yang telah diraih. Dari segi kepermimpinan informan menunjukan sosok kepemimpinan dalam membentuk personal branding dengan berupa pengakuan dalam hal penghargaan yang diraihnya sebagai pilot selebgram yang dimana diketahui bahwa sebagai pilot selebgram memiliki peran penting dalam hal membantu mengedukasi masyarakat Indonesia seputar dunia penerbangan, yang Vincent Raditya tunjukan dengan menunggah aktivitas dalam pesawat dan memotivasi kaum milenial agar menyukai dunia aviasi supaya tidak takut terbang. Dengan adanya penghargaan tersebut mampu memposisikan diri sebagai pemimpin yang dapat memberikan arahan ditengah ketidakpastian yang dihadapi masyarakat dan memberikan solusi dari permasalahan yang ada.

3) Kepribadian (The Law of Personality) :

Personal branding Vincent Raditya yang kuat bisa diperoleh karena ia mampu menjadi diri sendiri dengan kepribadian yang baik, apa adanya, humoris, serta mau berbaur dengan masyarakat disekitarnya yang ditunjukan dengan jiwa sosial yang ia miliki sebagai selebgram saat kegiataan menjadi tamu undangan suatu acara ataupun kegiatan kesehariannya saat bersama dengan teman dan keluarganya. Terlihat dari beragam foto dan video yang diunggah melalui akun sosial media Instagram Vincent Raditya sehingga dapat menciptakan citra yang terkait dengan personal branding nya.

4) Perbedaan (The Law of Distinctiveness) :

Sebuah personal branding perlu di publikasikan dengan cara yang berbeda, dalam hal ini Vincent Raditya menunjukan perbedaan dalam membentuk personal branding dengan tidak hanya memperkenalkan brand sebagai selebgram pilot, namun juga melalui hobi dan keahliannya dalam bermain alat musik dan bernyanyi. Adanya perbedaan dalam memperkenalkan brand tersebut yang ditunjukan oleh Vincent Raditya menjadikan personal brand nya lebih menonjol dari yang lainnya. Dalam membentuk personal branding, hal ini merupakan suatu keharusan sehingga personal branding yang tercipta bisa menjadi kuat dan efektif.

\section{5) Terlihat (The Law of Visibility):}

Melalui Instagram Vincent Raditya aktif mengunggah foto dan video baik kegiatan saat bertugas sebagai pilot maupun kegiatan kesehariannya agar dapat dilihat secara terus menerus oleh publik dan ia juga selalu mengadakan kegiatan meet and greet dengan followers nya setiap bulan agar bisa dekat dengan pengikutnya dan bisa saling mengenal secara langsung. Sehingga Citra sebagai selebgram yang dekat dengan khalayak secara konsisten ia lakukan di setiap bulannya.

6) Kesatuan (The Law of Unity) : 
Dalam hal ini Vincent Raditya menunjukan adanya kesatuan antara kepribadian yang ia miliki sesuai dengan apa yang ditentukan oleh brand. Citra yang ingin Vincent Raditya tampilkan dalam bentuk personal branding melalui Instagram sejalan dengan apa yang dilakukan di kesehariannya. Dalam hal ini ia menampilkan aktivitas kesehariannya baik berupa keseharian sebagai selebgram ataupun kesehariannya sebagai pribadi di ruang akun Instagram Vincent Raditya untuk menunjukan bahwa adanya kesatuan dengan apa yang ditampilkan ke publik dengan apa yang ia lakukan di kesehariannya tanpa ada rekayasa serta kepribadiannya sebagai pribadi sejalan dengan apa yang ditentukan oleh brand sebagai selebgram pilot.

7) Keteguhan (The Law of Persistence) :

Vincent Raditya termasuk orang yang konsisten dan mengikuti perkembangan zaman untuk membentuk personal branding nya dimana ia tidak hanya membentuk personal branding di kehidupan sehari-hari tetapi juga memanfaatkan media sosial seperti Instagram yang menjadi trend di lingkunngannya untuk memperlihatkan eksistensi dirinya dan juga untuk beraktualisasi sehingga menciptakan citra tersendiri bagi dirinya, dengan membagikan informasi berupa kegiatan selebgram pilot ataupun kegiatan pribadi.

\section{8) Nama Baik (The Law of Goodwill) :}

Vincent Raditya dalam menjaga nama baiknya ia tunjukan dengan jiwa sosial serta beretika baik dalam berkomunikasi dengan siapapun, begitupun di akun sosial media Instagram. Vincent Raditya menjaga nama baiknya di Instagram dengan tidak menggunggah konten atau foto yang yang dapat merusak citranya serta ia tidak menggunakan bahasa kasar untuk membalas komentar yang ada.

Menurut Fombrun (2007), dalam bukunya yang berjudul "Reputation" menjelaskan bahwa ada empat sisi reputasi yang perlu ditangani, yaitu:

1. Credibility

Vincent Raditya dapat mempertahankan kredibilitasnya di dalam media sosial Instagram dengan terus menerus mengunggah konten-konten yang menarik di Instagram yang bertujuan untuk menjadi media komunikasi antara Vincent Raditya dengan para pengikut (followers) nya. Membagikan informasi-informasi menarik dan terbaru agar akun Instagram nya tetap eksis dan stabil sehingga tidak kehilangan pengikut.

\section{Trustworthiness}

Vincent Raditya sangat mementingkan kepercayaan di dalam proses membentuk personal branding nya di Instagram. Vincent Raditya memberikan informasi-informasi yang dapat dipercaya, memberikan review atau kilasan produk yang digunakan dengan jujur dan apa adanya, membentuk citra yang dapat dipercaya oleh pengikut (followers) nya di media sosial.

\section{Reliability}

Vincent Raditya adalah seorang pilot yang memiliki reputasi nama yang baik di dunia penerbangan, tidak hanya itu Vincent Raditya juga membangun tempat simulasi penerbangan bagi masyarakat yang ingin 
merasakan cara menerbangkan pesawat dan bahkan membangun sekolah khusus pilot bagi masyarakat umum yang mempunyai cita-cita menjadi seorang pilot dan ingin mendapatkan lisensi penerbangan secara resmi. Profesionalitas dan reliabilitas sangatlah dipegang erat oleh seorang Vincent Raditya untuk menjaga mutu, jasa dan menjamin terlaksananya pelayanan prima yang diterima oleh konsumen.

\section{Responsibility}

Vincent Raditya merupakan seseorang yang sangat bertanggung jawab, pada salah satu konten video yang dibuat oleh Vincent Raditya yang melakukan penerbangan G Force / Zero Gravity sehingga menyebabkan lisensi penerbangan pesawat single engine di cabut. Vincent Raditya bertanggung jawab dan menerima konsekuensi dengan lapang dada atas perbuatan yang dilakukan.

\section{Simpulan}

Berdasarkan hasil pembahasan mengenai Analisis personal branding selebgram Vincent Raditya di Instagram dalam membentuk personal branding, maka dapat disimpulkan bahwa Vincent Raditya dalam membentuk personal branding nya sesuai dengan teori yang digunakan yaitu teori The Eight Law Of Personal Branding dan reputasi dalam pengaplikasiannya, Vincent Raditya memanfaatkan Instagram sebagai wadah untuk memposting segala aktivitasnya baik aktifitas yang berhubungan dengan profesinya sebagai pilot, seperti saat mengadakan kegiatan meet and greet mengenai program kerja yang diagendakan setiap bulannya di lingkungan masyarakat ataupun tentang aktifitas kesehariannya sebagai pribadi seperti saat bersama dengan sahabat, keluarga ataupun yang lainnya dengan menggunakan fiturfitur yang ada di dalam Instagram sebagai sarana untuk mengkomunikasikan atau mempublikasikan hal tersebut dengan gaya dan ciri khasnya yang unik sehingga dapat menarik simpatik dan perhatian serta membentuk persepsi positif dari khalayak publik dari persepsi positif yang tercipta tersebut, tentunya personal branding yang di bentuk Vincent Raditya yang memiliki prestasi dan keunggulan di bidang dunia aviasi serta memiliki jiwa sosial di lingkungan masyarakat dapat melekat dengan kuat di benak dan di hati masyarakat ataupun khalayak yang melihat.

\section{Ucapan Terima Kasih}

Peneliti mengucapkan terima kasih kepada narasumber utama yaitu Vincent Raditya dan juga narasumber pengikut (followers) yang telah memberikan kesempatan dan waktu dalam konteks berbagi informasi secara mendalam. Peneliti juga mengucapkan terima kasih terhadap teman-teman yang telah bersedia mendukung, menemani dalam penyusunan penelitian ini.

\section{Daftar Pustaka}

Montaya, Peter., Vandehey, Tim. (2002). The Personal Branding Phenomenon. United State : Peter Montaya Incorporated.

Raditya, Vincent. (2019). Captain Vincent Raditya. Jakarta : Romancious. 